Emir. J. Food Agric. 2011. 23 (2): 164-177

http://ejfa.info/

\title{
Evaluation of sweet potato (Ipomoea batatas L.) performance and soil properties under tillage methods and poultry manure levels
}

\author{
T. M. Agbede ${ }^{1 *}$ and A. O. Adekiya ${ }^{2}$ \\ ${ }^{1}$ Department of Agricultural Engineering Technology, Rufus Giwa Polytechnic, Owo, Ondo State, \\ Nigeria; ${ }^{2}$ Department of Crop, Soil and Pest Management, Federal University of Technology, \\ Akure, Ondo State, Nigeria
}

\begin{abstract}
Research study on the effect of tillage systems and application rate of poultry manure on sweet potato (Ipomoea batatas) in Alfisol of southwest Nigeria is lacking. Field trials were conducted in 2006, 2007 and 2008 cropping seasons on an Alfisol (Oxic Tropuldalf) at Owo in rainforest zone of southwest Nigeria. The trials consisted of the factorial combinations of two tillage methods (manual clearing and conventional tillage) and four manure levels $(0,5,10$ and $15 \mathrm{t} / \mathrm{ha})$ arranged in a randomized complete block design and replicated three times. Conventional tillage alone (CTo) resulted in lower soil N, P, K, $\mathrm{Ca}, \mathrm{Mg}$ and soil organic $\mathrm{C}$ and better leaf $\mathrm{N}, \mathrm{P}, \mathrm{K}, \mathrm{Ca}$ and $\mathrm{Mg}$ concentrations, growth and yield of sweet potato compared with manually cleared $(\mathrm{MCo})$ plots. The better performance of sweet potato under conventional tillage (CTo) was adduced to reduced bulk density. Bulk density was negatively correlated with yield. Conventional tillage alone (CTo) improves sweet potato tuber yield by 62,55 and $42 \%$ in 2006 , 2007 and 2008, respectively compared with manual clearing alone (MCo). In both the manually cleared and conventionally tilled plots, soil organic $\mathrm{C}, \mathrm{N}, \mathrm{P}, \mathrm{K}, \mathrm{Ca}, \mathrm{Mg}$ and water content increased with amount of poultry manure, while soil $\mathrm{pH}$, bulk density and temperature were reduced. Yields given by 5, 10 and 15 t/ha poultry manure were not significantly different under both manually cleared and conventionally tilled treatments. Conventional tillage plus $5 \mathrm{t} /$ ha poultry manure $(\mathrm{CT}+5 \mathrm{PM})$ produced the highest overall yield. Compared with manual clearing alone $(\mathrm{MCo})$ and conventional tillage alone (CTo), conventional tillage plus $5 \mathrm{t} /$ ha poultry manure $(\mathrm{CT}+5 \mathrm{PM})$ improved tuber yield of sweet potato by 117 and $43 \%$, respectively. Therefore the use of $5 \mathrm{t}$ /ha poultry manure with conventional tillage is recommended for sweet potato production on an Alfisol of southwest Nigeria.
\end{abstract}

Keywords: Tillage, sweet potato, poultry manure, bulk density, nutrient concentrations.

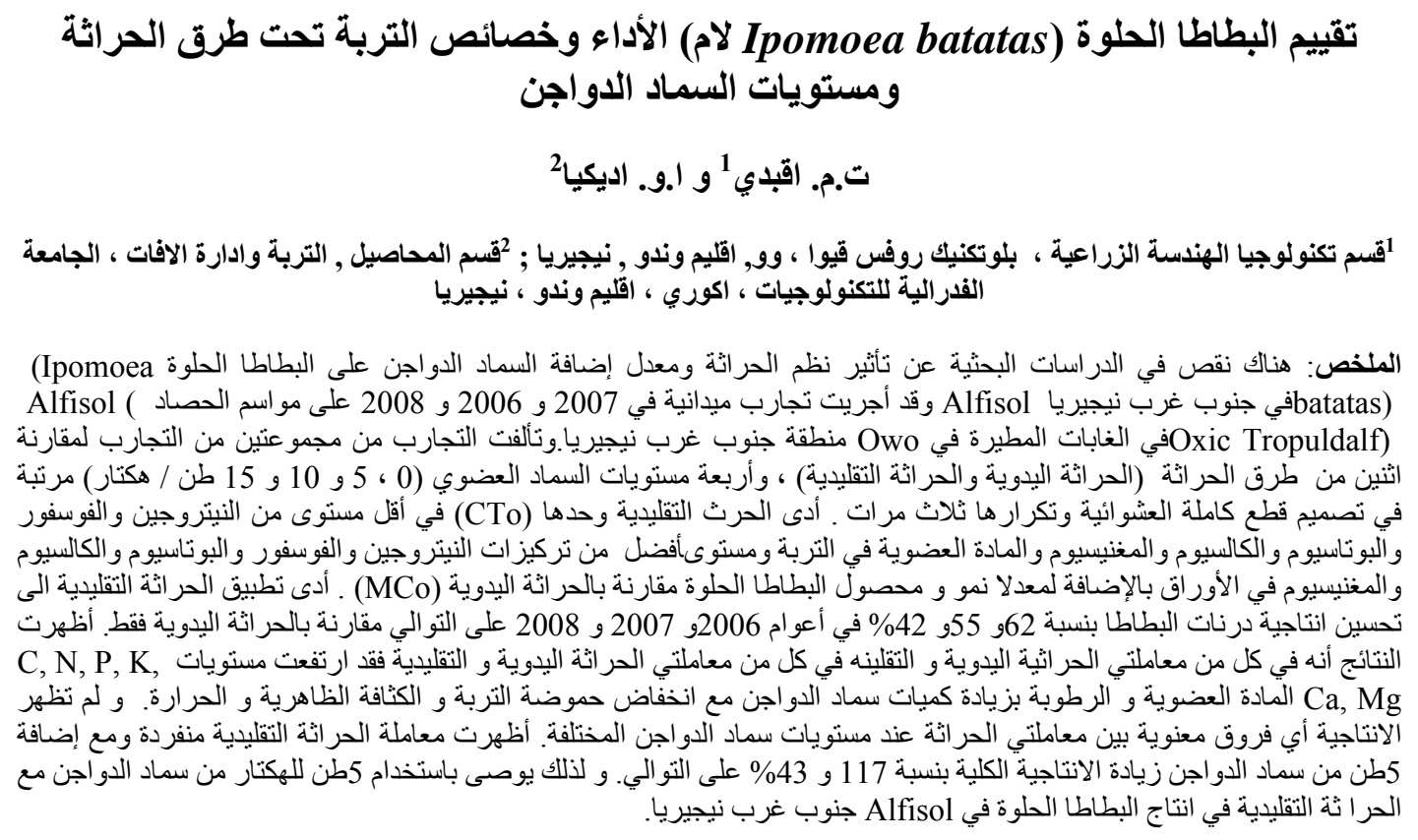

${ }^{*}$ Corresponding Author, Email: agbedetm@yahoo.com 


\section{Introduction}

With the increasing population pressure in tropical Africa, shifting cultivation is no longer sustainable and the length of traditional bush fallow for maintaining the productivity of the soil is becoming shorter (Mbah and Mbagwu, 2006). Therefore continuous cultivation of crop like sweet potato (Ipomoea batatas Lin) on the same land will lead to soil nutrient exhaustion and low yield. Moreso, sweet potato like any other root tuber crops is a heavy feeder exploiting greater volume of soil for nutrient and water (Osundare, 2004). Because of the fragile nature of tropical soils and especially Alfisol of the study area, appropriate and integrated soil management is necessary for sustaining high soil and crop productivity. According to Zingore et al. (2003), the soils are poor in organic matter and available nutrients and hence productivity and sustainability decline over time.

Two cultural practices that can moderate the soil organic matter, sustain the productivity of tropical soils and influence the performance of sweet potato is appropriate tillage and organic manure application. Nyakatawa et al. (2001) suggested that it is possible to increase yields of crops on physically degraded soils by using organic resources such as manure for soil fertility improvement after adopting appropriate tillage systems. Appropriate soil tillage or seedbed type can be a suitable alternative to enhanced nutrient availability to crop and therefore reduce money spend on chemical fertilizers (Adekiya and Ojeniyi, 2002).

The importance of no-tillage in soil and water conservation and growth and yields of crops in Nigeria had been reported (Ojeniyi and Adekayode, 1999; Agbede, 2008; Agbede and Ojeniyi, 2009). For large scale production of crops especially sweet potato, the use of mechanized tillage is inevitable. There had been no study to compare traditional farmers' manual clearing (zero tillage without mulch) with mechanized or conventional tillage as it affects the performance of sweet potato on Alfisol of southwest Nigeria. Few studies carried out were outside the Alfisol of southwest Nigeria. For example, Midmore
(1991) in Peru, found no significant differences in root yield of sweet potato under row-ridge, two-row bed, on-the flat and row furrow. Study carried out on deep Ultisol of southeast Nigeria gave contradictory results when study showed that conventional tillage out-yielded no-tillage system (Anikwe and Ubochi, 2007). Therefore studies on the response of sweet potato to tillage methods have produced inconclusive and controversial results.

Organic manure on the other hand is known to be effective in maintenance of adequate supply of organic matter in soils with attendant improvement in soil physical and chemical conditions and enhanced crop performance (Obi and Ebo, 1995; Ikpe and Powel, 2003; Ano and Agwu, 2005). Large quantities of organic wastes such as poultry manure are available in urban centre in Nigeria where they pose disposal problems and environmental hazards and are effective source of nutrient for tuber crop like sweet potato. Ikpe et al. (1999) reported that about $75 \%$ of farmers in the forest zone of West Africa keep livestock predominantly goat and poultry. The use of poultry manure for sweet potato production has not received adequate research attention in southwest Nigeria. The application rate of poultry manure for sweet potato has not been documented. Farmers need to be given specific application rate on how organic manure should be applied. There has not been research study on the implications of tillage-poultry manure combination on soil properties and performance of sweet potato in southwest Nigeria. Therefore the aim of this study was to investigate effect of tillage methods (conventional tillage and manual clearing and different levels of poultry manure on the soil physical and chemical properties, leaf nutrient concentration, growth and yield of sweet potato.

\section{Materials and Methods Site description and treatments}

A 3-year field experiment was carried out at Owo $\left(7^{\circ} 12^{\prime} \mathrm{N}, 5^{\circ} 35^{\prime} \mathrm{E}\right)$ in the forestsavanna transition zone of southwest Nigeria in 2006, 2007 and 2008 growing seasons. The 
soil in Owo area is an Alfisol (Oxic Tropuldalf) (USDA) or Luvisol (FAO) derived from quartz, gneiss and schist. There are two rainy seasons, one from March to July and the other is from mid-August to November. The rainfall totals in 2006, 2007 and 2008 were 1241,1335 and $1137 \mathrm{~mm}$, respectively. The pan-evaporation values were 1339, 1295 and $1326 \mathrm{~mm}$, respectively while the mean values of air temperature were 28,30 and $29^{\circ} \mathrm{C}$, respectively. Owo is located in the forestsavanna transition zone. The experiments followed 2 years of bush fallow. The values of the physical and chemical properties of the surface soil $(0-20 \mathrm{~cm})$ before experimentation were determined.

The trial each year consisted of $2 \times 4$ factorial combinations of two tillage methods (manual clearing and conventional tillage) and four poultry manure levels $(0,5,10$ and 15 t/ha). The eight treatments were (a) manual clearing alone (MCo): manual clearing with cutlass and packing away of the debris, (b) manual clearing plus $5 \mathrm{t} / \mathrm{ha}$ poultry manure (MC + 5 PM), (c) manual clearing plus 10 t/ha poultry manure $(\mathrm{MC}+10 \mathrm{PM})$, (d) manual clearing plus $15 \mathrm{t} /$ ha poultry manure $(\mathrm{MC}+15$ $\mathrm{PM})$, (e) conventional tillage alone (CTo): ploughing to a depth of $20 \mathrm{~cm}$ followed by harrowing and ridging, (f) conventional tillage plus $5 \mathrm{t} /$ ha poultry manure $(\mathrm{CT}+5 \mathrm{PM}),(\mathrm{g})$ conventional tillage plus $10 \mathrm{t} / \mathrm{ha}$ poultry manure $(\mathrm{CT}+10 \mathrm{PM})$ and $(\mathrm{h})$ conventional tillage plus $15 \mathrm{t} /$ ha poultry manure $(\mathrm{CT}+15$ PM). The eight treatments were factorially arranged in a randomized complete block design and replicated three times. The same treatment was allotted to each plot for the 3 years of study.

\section{Planting of sweet potato and poultry manure application}

The experimental plot size in each trial was $12 \mathrm{~m} \times 10 \mathrm{~m}$. In order to minimize interference, there was a $4 \mathrm{~m}$ wide guard strip of sweet potato between blocks and $3 \mathrm{~m}$ between plots. After land preparation, planting of sweet potato vines (Owo local variety) about $40 \mathrm{~cm}$ long were done in May each year at a spacing of $1 \mathrm{mx} 1 \mathrm{~m}$ giving a population of 10,000 plants/ha. Before application, the poultry manure was air-dried and sieved with 2 - $\mathrm{mm}$ sieve. The manure was applied in ring form at planting, thoroughly worked into the soil with a hoe. Weeding was done manually at 3 and 8 weeks after planting in each experiment.

\section{Determination of soil properties}

One month after planting sweet potato/poultry manure application, determination of certain soil physical properties in all plots commenced and this was done at one-month interval on four occasions for each year. Six samples (4 cm diameter, 10 $\mathrm{cm}$ high) were collected at $0-10 \mathrm{~cm}$ depth from each plot using a steel core sampler and were used for the evaluation of bulk density, total porosity and gravimetric water content after oven-dried at $100^{\circ} \mathrm{C}$ for $24 \mathrm{~h}$. Total porosity was calculated from the values of bulk density and particle density. Soil temperature was determined at $15.00 \mathrm{~h}$ with a soil thermometer inserted to $10 \mathrm{~cm}$ depth. Six readings were made per plot at each sampling time at 1 -month interval and mean data were computed.

Prior to commencement of experiment in 2006, soil samples randomly collected from 0 $20 \mathrm{~cm}$ depth were thoroughly mixed inside a plastic bucket to form a composite which was later analysed for physical and chemical properties. At the beginning of harvest in 2007 (second crop) and 2008 (third crop) (i.e. 5 months after planting), another set of composite samples were collected per plot and similarly analysed for routine chemical analysis as described by Carter (1993). The soil samples were air-dried and sieved using a $2 \mathrm{~mm}$ sieve before making the determinations. Soil organic carbon was determined by the procedure of Walkley and Black using the dichromate wet oxidation method (Nelson and Sommers, 1996), total $\mathrm{N}$ was determined by micro-Kjeldahl digestion method (Bremner, 1996), available $P$ was determined by Bray-1 extraction followed by molybdenum blue colorimetry (Frank et al., 1998). Exchangeable $\mathrm{K}, \mathrm{Ca}$ and $\mathrm{Mg}$ were extracted using $1.0 \mathrm{~N}$ ammonium acetate. Thereafter, $\mathrm{K}$ was 
determined using a flame photometer and $\mathrm{Ca}$ and $\mathrm{Mg}$ were determined by the EDTA titration method (Hendershot and Lalande, 1993). Soil $\mathrm{pH}$ was determined in soil-water (1:2) medium using the digital electronic $\mathrm{pH}$ meter (Ibitoye, 2006). Particle-size analysis was done using Bouyoucos hydrometer method (Sheldrick and Hand Wang, 1993). Soil bulk density was determined using the core method (Campbell and Henshall, 1991).

\section{Leaf and poultry manure analysis}

In 2007 and 2008, leaf samples were collected at 3 months after planting from five plants per plot for chemical analysis. Leaf samples were oven-dried for $24 \mathrm{~h}$ at $80^{\circ} \mathrm{C}$ and ground in a Willey-mill. Leaf $\mathrm{N}$ was determined by micro-Kjeldahl digestion method. Samples were dry ashed in a furnace at $450^{\circ} \mathrm{C}$ for $6 \mathrm{~h}$ and extracted using $10 \% \mathrm{HCl}$ for determination of $\mathrm{P}, \mathrm{K}, \mathrm{Ca}$ and $\mathrm{Mg}$. Leaf $\mathrm{P}$ was determined colorimetrically by the vanadomolybdate method, $\mathrm{K}$ was determined using flame photometer, and $\mathrm{Ca}$ and $\mathrm{Mg}$ were determined using atomic absorption spectrophotometer (AOAC, 1997). Air-dried and ground poultry manure samples were sieved through a $2 \mathrm{~mm}$ sieve and analysed for organic $\mathrm{C}, \mathrm{N}, \mathrm{P}, \mathrm{K}, \mathrm{Ca}$ and $\mathrm{Mg}$ using the method described by Okalebo et al. (1993).

\section{Growth and yield parameters}

Twenty plants were randomly selected per plot for the determination of growth and yield parameters. Leaf area (by graphical method) was determined at 3 months after planting while vine length and tuber weight were determined at harvest (i.e. 5 months after planting).

\section{Statistical analysis}

The data collected were subjected to analysis of variance (ANOVA) and the treatment means were separated using Duncan's multiple range test at 5\% probability level (Hinkelman and Kempthorne, 1994).

\section{Results}

The data presented in Table 1 are the results of soil physical and chemical properties before the start of the experiment and the chemical composition of poultry manure used. The soil is sandy loam with $\mathrm{pH}$ of 7.1. The soil bulk density of $1.44 \mathrm{Mg} \mathrm{m}^{-3}$ is high for sweet potato and other tuber crops (Agbede and Ojeniyi, 2003). The organic $C$ of $2.71 \mathrm{~g}$ $\mathrm{kg}^{-1}$ and total nitrogen of $0.15 \mathrm{~g} \mathrm{~kg}^{-1}$ were low. The available $\mathrm{P}$ of $15.9 \mathrm{mg} \mathrm{kg}$ and the exchangeable bases $(\mathrm{K}, \mathrm{Ca}$, and $\mathrm{Mg}$ ) were adequate. The poultry manure used was relatively high in $\mathrm{N}, \mathrm{P}, \mathrm{K}$ and $\mathrm{Ca}$. The organic $\mathrm{C}, \mathrm{N}, \mathrm{P}, \mathrm{K}, \mathrm{Ca}$ and $\mathrm{Mg}$ constituents are expected to improve the fertility of the experimental soil and tuber yield of sweet potato.

\section{Soil physical properties}

Tillage methods significantly influenced soil temperature, bulk density, total porosity and water content in the 3 years considered (Table 2). Manual clearing alone (MCo) consistently produced the least soil temperature compared with conventional tillage alone (CTo). However, with the application of poultry manure, the least soil temperature was consistently recorded by $(\mathrm{MC}+10 \mathrm{PM})$ and $(\mathrm{MC}+15 \mathrm{PM})$ while the highest was recorded by CTo in all the treatments considered. There were no significant differences between soil temperatures of $(\mathrm{MC}+$ $10 \mathrm{PM})$ and $(\mathrm{MC}+15 \mathrm{PM})$ and between $(\mathrm{CT}+$ $5 \mathrm{PM})$ and $(\mathrm{CT}+10 \mathrm{PM})$. In the 3 years, tillage methods significantly influenced soil bulk density. MCo had higher bulk density when compared with CTo. With poultry manure application, the least value was consistently recorded by $(\mathrm{CT}+15 \mathrm{PM})$ while the highest was recorded by MCo. There were reductions in soil bulk density with increasing levels of poultry manure. In the 3 years, the order were $\mathrm{MCo}>(\mathrm{MC}+5 \mathrm{PM}), \mathrm{CTo}$ and $(\mathrm{MC}+10 \mathrm{PM})$ $>(\mathrm{MC}+15 \mathrm{PM})$ and $(\mathrm{CT}+5 \mathrm{PM})>(\mathrm{CT}+10$ $\mathrm{PM})>(\mathrm{CT}+15 \mathrm{PM})$. 
Table 1. Mean \pm standard deviation of soil physical and chemical properties $(0-20 \mathrm{~cm}$ depth $)$ of the experimental site before planting in $\mathbf{2 0 0 6}$ and chemical composition of poultry manure used in 2006, 2007 and 2008.

\begin{tabular}{|c|c|c|c|}
\hline \multicolumn{2}{|l|}{ Soil property } & \multicolumn{2}{|c|}{ Value } \\
\hline \multicolumn{2}{|l|}{ Sand $\left(\mathrm{g} \mathrm{kg}^{-1}\right)$} & \multicolumn{2}{|c|}{$690 \pm 8.8$} \\
\hline \multicolumn{2}{|l|}{ Silt $\left(\mathrm{g} \mathrm{kg}^{-1}\right)$} & \multicolumn{2}{|c|}{$130 \pm 5.6$} \\
\hline \multicolumn{2}{|l|}{ Clay $\left(\mathrm{g} \mathrm{kg}^{-1}\right)$} & \multicolumn{2}{|c|}{$180 \pm 4.9$} \\
\hline \multicolumn{2}{|l|}{ Textural class } & \multicolumn{2}{|c|}{ Sandy loam } \\
\hline \multicolumn{2}{|l|}{$\mathrm{pH}$ (water) } & \multicolumn{2}{|c|}{$7.1 \pm 0.3$} \\
\hline \multicolumn{2}{|c|}{ Bulk density $\left(\mathrm{Mg} \mathrm{m}^{-3}\right)$} & \multicolumn{2}{|c|}{$1.44 \pm 0.04$} \\
\hline \multicolumn{2}{|c|}{ Total porosity $(\%, \mathrm{v} / \mathrm{v})$} & \multicolumn{2}{|c|}{$45.7 \pm 0.5$} \\
\hline \multicolumn{2}{|c|}{ Organic carbon $\left(\mathrm{g} \mathrm{kg}^{-1}\right)$} & \multicolumn{2}{|c|}{$2.71 \pm 0.06$} \\
\hline \multicolumn{2}{|c|}{ Total $\mathrm{N}\left(\mathrm{g} \mathrm{kg}^{-1}\right)$} & \multicolumn{2}{|c|}{$0.15 \pm 0.02$} \\
\hline \multicolumn{2}{|c|}{ Available $\mathrm{P}\left(\mathrm{mg} \mathrm{kg}^{-1}\right)$} & \multicolumn{2}{|c|}{$15.9 \pm 0.6$} \\
\hline \multicolumn{2}{|c|}{ Exchangeable $\mathrm{K}\left(\mathrm{cmol} \mathrm{kg}^{-1}\right)$} & \multicolumn{2}{|c|}{$0.69 \pm 0.02$} \\
\hline \multicolumn{2}{|c|}{ Exchangeable $\mathrm{Ca}\left(\left(\mathrm{cmol} \mathrm{kg}^{-1}\right)\right.$} & \multicolumn{2}{|c|}{$8.7 \pm 0.3$} \\
\hline \multicolumn{2}{|c|}{ Exchangeable $\mathrm{Mg}\left(\left(\mathrm{cmol} \mathrm{kg}^{-1}\right)\right.$} & \multicolumn{2}{|c|}{$1.5 \pm 0.04$} \\
\hline \multicolumn{4}{|c|}{ Poultry manure } \\
\hline Nutrient & 2006 value & 2007 value & 2008 value \\
\hline $\mathrm{pH}$ & 6.8 & 6.9 & 6.8 \\
\hline Organic C $(\%)$ & 29.5 & 23.6 & 27.1 \\
\hline Nitrogen $(\%)$ & 4.31 & 3.03 & 3.23 \\
\hline $\mathrm{C}: \mathrm{N}$ & 6.8 & 7.8 & 8.4 \\
\hline Phosphorus (\%) & 0.83 & 0.72 & 0.61 \\
\hline Potassium (\%) & 2.2 & 2.4 & 1.9 \\
\hline Calcium (\%) & 1.4 & 1.5 & 1.8 \\
\hline Magnesium (\%) & 0.58 & 0.43 & 0.58 \\
\hline
\end{tabular}

The bulk density recorded for the treatments were matched by the porosity recorded. MCo expectedly had the least porosity while $(\mathrm{CT}+15$ $\mathrm{PM}$ ) had the highest porosity. Soil water content in the 3 years was in the decreasing order of $(\mathrm{MC}+$ $15 \mathrm{PM})$ and $(\mathrm{MC}+10 \mathrm{PM})>(\mathrm{MC}+5 \mathrm{PM}),(\mathrm{CT}+$ $15 \mathrm{PM})$ and $(\mathrm{CT}+10 \mathrm{PM})>\mathrm{MCo}>(\mathrm{CT}+5$ $\mathrm{PM})>\mathrm{CT}$.

\section{Soil and leaf nutrient concentrations}

The effect of tillage methods and poultry manure on soil chemical properties is shown in Table 3. MCo had significantly higher concentration of soil organic $\mathrm{C}, \mathrm{N}, \mathrm{P}, \mathrm{K}, \mathrm{Ca}$ and $\mathrm{Mg}$ compared with $\mathrm{CTo}$ in both years. With applications of poultry manure, soil chemical properties tended to improve with increasing levels of poultry manure application. In all cases, concentrations of nutrients were lower in CTo compared with other treatments. There were percentage decreases in soil organic $\mathrm{C}$ over the years. The percentage decreases in soil organic $\mathrm{C}$ were
15.8 and 23.2\% for MCo in 2007 and 2008, respectively, while the percentage decreases were 32.8 and $35.5 \%$ for CTo in 2007 and 2008 , respectively. The values of soil $\mathrm{pH}$ between MCo and CTo in both years were not significantly different. Increasing the levels of poultry manure from 0 to $15 \mathrm{t} / \mathrm{ha}$ decreases soil $\mathrm{pH}$. The least soil $\mathrm{pH}$ was recorded by $(\mathrm{CT}+15$ $\mathrm{PM})$ and $(\mathrm{MC}+15 \mathrm{PM})$ in both years.

Table 4 shows the effect of tillage methods and poultry manure on leaf nutrient concentration of sweet potato in 2007 and 2008. CTo produces significantly higher concentration of leaf $\mathrm{N}, \mathrm{P}, \mathrm{K}, \mathrm{Ca}$ and $\mathrm{Mg}$ compared with MCo. The values of leaf N, P and K increases with the levels of poultry manure in both the manually cleared and conventionally tilled plots. In almost all cases, the values of leaf $\mathrm{Ca}$ and $\mathrm{Mg}$ between $(\mathrm{MC}+5 \mathrm{PM}),(\mathrm{MC}+10 \mathrm{PM})$ and $(\mathrm{MC}+15 \mathrm{PM})$, and between $(\mathrm{CT}+5 \mathrm{PM})$, $(\mathrm{CT}+10 \mathrm{PM})$ and $(\mathrm{CT}+15 \mathrm{PM})$ were not significantly different. 
Table 2. Effect of tillage methods and poultry manure on soil physical properties $(0-10 \mathrm{~cm}$ depth).

\begin{tabular}{|c|c|c|c|c|c|c|c|c|c|c|c|c|c|c|c|c|}
\hline \multirow{2}{*}{ Treatment } & \multicolumn{4}{|c|}{ Bulk density $\left(\mathrm{Mg} \mathrm{m}^{-3}\right)$} & \multicolumn{4}{|c|}{ Total porosity $(\% \mathrm{v} / \mathrm{v})$} & \multicolumn{4}{|c|}{ Water content $\left(\mathrm{g} \mathrm{kg}^{-1}\right)$} & \multicolumn{4}{|c|}{ Temperature $\left({ }^{\circ} \mathrm{C}\right)$} \\
\hline & 2006 & 2007 & 2008 & Mean & 2006 & 2007 & 2008 & Mean & 2006 & 2007 & 2008 & Mean & 2006 & 2007 & 2008 & Mean \\
\hline MCo & $1.44 \mathrm{a}$ & $1.45 \mathrm{a}$ & $1.45 \mathrm{a}$ & 1.45 & $45.7 \mathrm{f}$ & $45.3 \mathrm{f}$ & $45.4 \mathrm{f}$ & 45.5 & $115 \mathrm{c}$ & $110 \mathrm{c}$ & $112 \mathrm{c}$ & 112 & $28.5 b$ & $29.8 \mathrm{~b}$ & $29.4 \mathrm{~b}$ & 29.2 \\
\hline $\begin{array}{l}\mathrm{MC}+5 \\
\mathrm{t} / \mathrm{ha} \mathrm{PM}\end{array}$ & $1.26 \mathrm{~b}$ & $1.26 \mathrm{~b}$ & $1.26 \mathrm{~b}$ & 1.26 & $52.5 \mathrm{de}$ & $52.5 \mathrm{de}$ & $52.5 \mathrm{de}$ & 52.5 & $140 \mathrm{~b}$ & $134 b$ & $137 b$ & 137 & $25.1 \mathrm{c}$ & $27.9 \mathrm{c}$ & $26.5 \mathrm{c}$ & 26.5 \\
\hline $\begin{array}{l}\mathrm{MC}+10 \\
\text { t/ha PM }\end{array}$ & $1.19 \mathrm{bc}$ & $1.19 \mathrm{bc}$ & $1.19 \mathrm{bc}$ & 1.19 & $55.1 \mathrm{c}$ & $55.1 \mathrm{c}$ & $55.1 \mathrm{c}$ & 55.1 & $156 \mathrm{a}$ & $149 \mathrm{a}$ & $152 \mathrm{a}$ & 152 & $22.1 \mathrm{~d}$ & $25.0 \mathrm{~d}$ & $23.8 \mathrm{~d}$ & 23.6 \\
\hline CTo & $1.22 \mathrm{~b}$ & $1.23 \mathrm{~b}$ & $1.23 b$ & 1.23 & $54.0 \mathrm{~cd}$ & $53.6 \mathrm{~cd}$ & $53.8 \mathrm{~cd}$ & 53.8 & $90 \mathrm{e}$ & $85 \mathrm{e}$ & $87 \mathrm{e}$ & 87 & $32.7 \mathrm{a}$ & $34.5 \mathrm{a}$ & $33.6 \mathrm{a}$ & 33.6 \\
\hline $\begin{array}{l}\text { CT }+5 \\
\text { t/ha PM }\end{array}$ & $1.11 \mathrm{~cd}$ & $1.11 \mathrm{~cd}$ & $1.11 \mathrm{~cd}$ & 1.11 & $55.1 \mathrm{c}$ & $55.1 \mathrm{c}$ & $55.1 \mathrm{c}$ & 55.1 & $102 \mathrm{~d}$ & $101 \mathrm{~d}$ & $101 d$ & 101 & $29.1 \mathrm{~b}$ & $31.1 \mathrm{~b}$ & $30.2 b$ & 30.1 \\
\hline $\begin{array}{l}\mathrm{CT}+10 \\
\mathrm{t} / \mathrm{ha} \mathrm{PM}\end{array}$ & $1.00 \mathrm{e}$ & $1.00 \mathrm{e}$ & $1.00 \mathrm{e}$ & 1.00 & $62.3 \mathrm{ab}$ & $62.3 \mathrm{ab}$ & $62.3 \mathrm{ab}$ & 62.3 & $130 \mathrm{~b}$ & $131 b$ & $130 \mathrm{~b}$ & 130 & $28.1 \mathrm{~b}$ & $30.3 b$ & $29.3 b$ & 29.2 \\
\hline $\begin{array}{l}\mathrm{CT}+15 \\
\mathrm{t} / \mathrm{ha} \mathrm{PM}\end{array}$ & $0.92 \mathrm{f}$ & $0.92 \mathrm{f}$ & $0.92 \mathrm{f}$ & 0.92 & $65.7 \mathrm{a}$ & $65.3 \mathrm{a}$ & $65.4 \mathrm{a}$ & 65.4 & $135 b$ & $129 b$ & $132 b$ & 137 & $25.3 \mathrm{c}$ & $27.1 \mathrm{c}$ & $26.4 \mathrm{c}$ & 26.3 \\
\hline
\end{tabular}


Emir. J. Food Agric. 2011. 23 (2): 164-177

http://ejfa.info/

Table 3. Effect of tillage methods and poultry manure on soil chemical properties (0-20 cm depth) in 2007 and 2008.

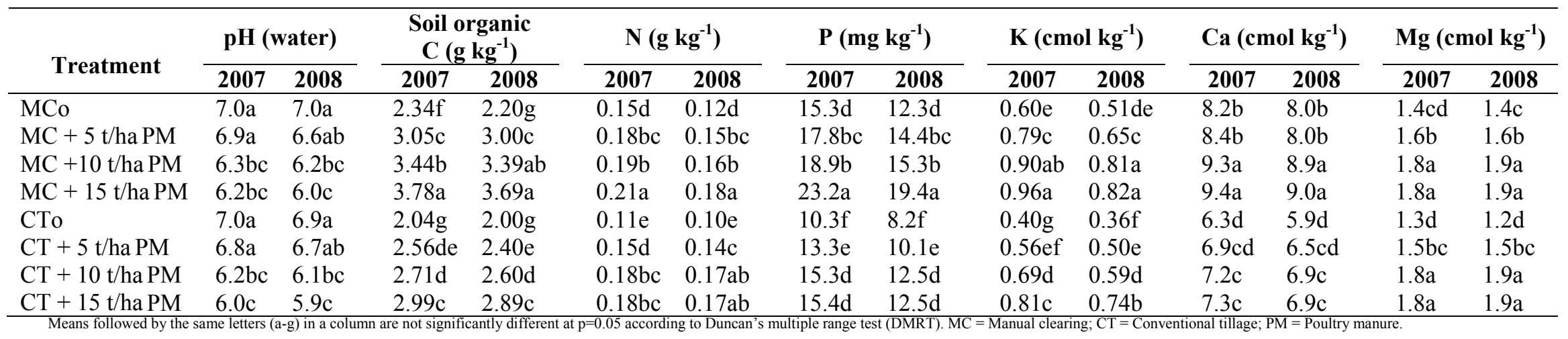


T. M. Agbede and A. O. Adekiya

Table 4. Effect of tillage methods and poultry manure on leaf nutrient concentration of sweet potato in 2007 and 2008.

\begin{tabular}{|c|c|c|c|c|c|c|c|c|c|c|}
\hline \multirow{2}{*}{ Treatment } & \multicolumn{2}{|c|}{$N\left(g 100 g^{-1}\right)$} & \multicolumn{2}{|c|}{$P\left(g 100 g^{-1}\right)$} & \multicolumn{2}{|c|}{$K\left(\mathrm{~g} 100 \mathrm{~g}^{-1}\right)$} & \multicolumn{2}{|c|}{$\mathrm{Ca}\left(\mathrm{g} 100 \mathrm{~g}^{-1}\right)$} & \multicolumn{2}{|c|}{$\operatorname{Mg}\left(\mathrm{g} 100 \mathrm{~g}^{-1}\right)$} \\
\hline & 2007 & 2008 & 2007 & 2008 & 2007 & 2008 & 2007 & 2008 & 2007 & 2008 \\
\hline MCo & $2.20 \mathrm{~g}$ & $2.10 \mathrm{~g}$ & $0.15 \mathrm{e}$ & $0.15 \mathrm{e}$ & $1.25 \mathrm{f}$ & $1.20 \mathrm{f}$ & $1.10 \mathrm{~d}$ & $1.00 \mathrm{~d}$ & $0.61 \mathrm{~d}$ & $0.56 \mathrm{~d}$ \\
\hline $\begin{array}{l}\mathrm{MC}+5 \\
\mathrm{t} / \mathrm{haPM}\end{array}$ & $2.45 \mathrm{f}$ & $2.35 \mathrm{f}$ & $0.18 \mathrm{~d}$ & $0.17 \mathrm{~d}$ & $1.46 \mathrm{e}$ & $1.40 \mathrm{e}$ & $1.22 \mathrm{bc}$ & $1.20 \mathrm{bc}$ & $0.69 \mathrm{c}$ & $0.68 \mathrm{c}$ \\
\hline $\begin{array}{l}\mathrm{MC}+10 \\
\mathrm{t} / \mathrm{ha} \mathrm{PM}\end{array}$ & $2.70 \mathrm{e}$ & $2.60 \mathrm{e}$ & $0.20 \mathrm{c}$ & $0.20 \mathrm{c}$ & $1.60 \mathrm{~d}$ & $1.56 \mathrm{~d}$ & $1.22 \mathrm{bc}$ & $1.19 \mathrm{bc}$ & $0.72 \mathrm{c}$ & $0.69 \mathrm{c}$ \\
\hline $\begin{array}{l}\mathrm{MC}+15 \\
\mathrm{t} / \mathrm{ha} \mathrm{PM}\end{array}$ & $3.00 \mathrm{~d}$ & $2.91 \mathrm{~d}$ & $0.24 b$ & $0.23 b$ & $1.78 \mathrm{c}$ & $1.70 \mathrm{c}$ & $1.23 \mathrm{bc}$ & $1.20 \mathrm{bc}$ & $0.72 \mathrm{c}$ & $0.68 \mathrm{c}$ \\
\hline СТo & $2.93 \mathrm{de}$ & $2.89 \mathrm{de}$ & $0.21 \mathrm{c}$ & $0.20 \mathrm{c}$ & $1.60 \mathrm{~d}$ & $1.56 \mathrm{~d}$ & $1.30 \mathrm{~b}$ & $1.25 b$ & $0.71 \mathrm{c}$ & $0.68 \mathrm{c}$ \\
\hline $\begin{array}{l}\mathrm{CT}+5 \\
\mathrm{t} / \mathrm{haPM}\end{array}$ & $3.30 \mathrm{c}$ & $3.21 \mathrm{c}$ & $0.24 b$ & $0.23 b$ & $1.85 \mathrm{bc}$ & $1.80 \mathrm{bc}$ & $1.44 \mathrm{a}$ & $1.39 \mathrm{a}$ & $0.79 b$ & $0.76 b$ \\
\hline $\begin{array}{l}\mathrm{CT}+10 \\
\mathrm{t} / \mathrm{ha} \mathrm{PM}\end{array}$ & $3.76 \mathrm{ab}$ & $3.55 \mathrm{~b}$ & $0.27 \mathrm{a}$ & $0.26 \mathrm{a}$ & $1.98 \mathrm{~b}$ & $1.90 \mathrm{~b}$ & $1.45 \mathrm{a}$ & $1.39 \mathrm{a}$ & $0.88 \mathrm{a}$ & $0.85 \mathrm{a}$ \\
\hline $\begin{array}{l}\mathrm{CT}+15 \\
\mathrm{t} / \mathrm{ha} \mathrm{PM}\end{array}$ & $3.96 \mathrm{a}$ & $3.90 \mathrm{a}$ & $0.28 \mathrm{a}$ & $0.27 \mathrm{a}$ & $2.23 \mathrm{a}$ & $2.20 \mathrm{a}$ & $1.44 \mathrm{a}$ & $1.38 \mathrm{a}$ & $0.81 \mathrm{a}$ & $0.84 \mathrm{a}$ \\
\hline
\end{tabular}

\section{Sweet potato performance}

Tillage methods and levels of poultry manure significantly influenced the growth and yield of sweet potato (Table 5). The growth indices are shown by vine length and leaf area. CTo significantly increased vine length and leaf area compared with MCo. With the application of poultry manure, vine length tended to increase with increasing level of poultry manure from 0 to $15 \mathrm{t} / \mathrm{ha}$ in both tillage methods. However, the leaf area given by 5,10 and 15 t/ha poultry manure under conventional tillage were not significantly different, likewise leaf area given by 5, 10 and 15 t/ha poultry manure for manually cleared plots were not significantly different. Averaged over the 3 years, the correlation coefficient (r) of -1 and -1 were recorded between soil bulk density and vine length and leaf area, respectively for $\mathrm{MCo}$ and CTo. Tillage methods and poultry manure applications significantly influenced sweet potato tuber yield. CTo improved the yield of sweet potato by $61.9,54.6$ and $41.5 \%$, respectively in 2006, 2007 and 2008 compared with MCo. Averaged over the 3 years, the correlation coefficient (r) of -1 was recorded between soil bulk density and tuber yield of MCo and CTo plots. Poultry manure application significantly improved tuber yield compared with MCo and CTo treatments. The yield given by 5,10 and 15 t/ha poultry manure under the manually cleared plots were not significantly different, likewise yield given by 5,10 and $15 \mathrm{t} /$ ha poultry manure under the conventionally tilled plots were not significantly different. Compared with $\mathrm{MCo}$ and CTo, ( $\mathrm{MC}+5 \mathrm{PM})$ improved sweet potato yield by 71.9 and $13.1 \%$, respectively and compared with $\mathrm{MCo}$ and CTo, (CT +5 PM) improved sweet potato tuber yield by 116.7 and $42.7 \%$, respectively.

\section{Discussion}

Tillage methods significantly influenced soil physical properties. Manual clearing alone (MCo) gave relatively high soil bulk density, water content and low soil temperature compared with conventional tillage alone (CTo). The higher bulk density of MCo compared with CTo could be attributed to non-tillage and compaction. This observation implies that continuous exposure of untilled soil to rainfall without tillage will increase the bulk density of the soil. Agbede and Ojeniyi (2003); Bankole and Ojeniyi (2005) and Agbede (2006) had earlier reported higher bulk density for zero tillage compared with tilled soils in southwest Nigeria. 
Table 5. Effect of tillage methods and poultry manure on growth and yield parameters in 2006, 2007 and 2008.

\begin{tabular}{|c|c|c|c|c|c|c|c|c|c|c|c|c|}
\hline \multirow[t]{2}{*}{ Treatments } & \multicolumn{4}{|c|}{ Vine length (m) } & \multicolumn{4}{|c|}{ Leaf area $\left(\mathrm{m}^{2}\right)$} & \multicolumn{4}{|c|}{ Tuber weight $\left(\mathrm{t} \mathrm{ha}^{-1}\right)$} \\
\hline & 2006 & 2007 & 2008 & Mean & 2006 & 2007 & 2008 & Mean & 2006 & 2007 & 2008 & Mean \\
\hline $\mathrm{MCo}$ & $1.75 \mathrm{e}$ & $1.59 \mathrm{e}$ & $1.67 \mathrm{e}$ & 1.67 & $0.60 \mathrm{~d}$ & $0.58 \mathrm{c}$ & $0.59 \mathrm{c}$ & 0.59 & $10.78 b$ & $10.50 \mathrm{~d}$ & $10.25 \mathrm{~d}$ & 10.57 \\
\hline $\mathrm{MC}+5 \mathrm{t} / \mathrm{ha} \mathrm{PM}$ & $2.15 \mathrm{~d}$ & $1.93 \mathrm{~d}$ & $2.00 \mathrm{~d}$ & 2.03 & $0.77 \mathrm{c}$ & $0.69 b$ & $0.74 \mathrm{~b}$ & 0.73 & $19.90 \mathrm{~b}$ & $18.10 \mathrm{~b}$ & $16.50 \mathrm{~b}$ & 18.17 \\
\hline $\mathrm{MC}+10 \mathrm{t} / \mathrm{ha} \mathrm{PM}$ & $2.52 \mathrm{c}$ & $2.44 \mathrm{c}$ & $2.44 \mathrm{c}$ & 2.47 & $0.79 \mathrm{c}$ & $0.73 b$ & $0.76 b$ & 0.76 & $20.03 b$ & $18.35 b$ & $16.75 b$ & 18.38 \\
\hline $\mathrm{MC}+15 \mathrm{t} / \mathrm{ha} \mathrm{PM}$ & $2.90 \mathrm{ab}$ & $2.71 \mathrm{ab}$ & $2.80 \mathrm{ab}$ & 2.80 & $0.81 \mathrm{c}$ & $0.75 b$ & $0.78 b$ & 0.78 & $20.35 b$ & $18.85 b$ & $17.20 \mathrm{~b}$ & 18.80 \\
\hline CTo & $2.15 d$ & $1.90 \mathrm{~d}$ & $2.01 \mathrm{~d}$ & 2.02 & $0.80 \mathrm{c}$ & $0.72 b$ & $0.76 b$ & 0.76 & $17.45 \mathrm{c}$ & $16.23 c$ & $14.50 \mathrm{c}$ & 16.06 \\
\hline $\mathrm{CT}+5 \mathrm{t} / \mathrm{ha} \mathrm{PM}$ & $2.51 \mathrm{c}$ & $2.40 \mathrm{c}$ & $2.40 \mathrm{c}$ & 2.44 & $0.94 \mathrm{ab}$ & $0.89 a$ & $0.92 \mathrm{a}$ & 0.92 & $22.40 \mathrm{a}$ & $23.08 \mathrm{a}$ & $23.25 \mathrm{a}$ & 22.91 \\
\hline $\mathrm{CT}+10 \mathrm{t} / \mathrm{ha} \mathrm{PM}$ & $2.89 \mathrm{ab}$ & $2.75 \mathrm{ab}$ & $2.82 \mathrm{ab}$ & 2.82 & $0.97 \mathrm{ab}$ & $0.92 \mathrm{a}$ & $0.95 \mathrm{a}$ & 0.95 & $23.00 \mathrm{a}$ & $23.63 a$ & $23.23 \mathrm{a}$ & 23.29 \\
\hline $\mathrm{CT}+15 \mathrm{t} / \mathrm{ha} \mathrm{PM}$ & $3.10 \mathrm{a}$ & $2.95 \mathrm{a}$ & $3.03 \mathrm{a}$ & 3.03 & $1.00 \mathrm{a}$ & $0.94 \mathrm{a}$ & $0.97 \mathrm{a}$ & 0.97 & $23.30 \mathrm{a}$ & $23.80 \mathrm{a}$ & $23.10 \mathrm{a}$ & 23.40 \\
\hline
\end{tabular}


The higher water content of MCo compared with CTo is consistent with its lower porosity. The turbulent movement of atmospheric air into soils which enhanced water evaporation occurs through larger pores (Ojeniyi and Adekayode, 1999; Ojeniyi et al., 1999). Ojeniyi et al. (1999) found that for sandy soils of southwest Nigeria, water content increased with bulk density. Hillet et al. (1975) had earlier reported that no-till plots were protected by a layer of low conductivity (dry soil) on the surface which reduces evaporation losses. CTo had relatively high soil temperature compared with MCo. The relative high value of soil temperature caused by CTo is consistent with its relatively low soil water content. Other studies confirmed that tillage treatments did cause significant difference in absolute soil temperature (Ojeniyi, 1990; Adekiya and Ojeniyi, 2002; Agbede and Ojeniyi, 2003).

The application of poultry manure improved soil physical properties in manure plots compared with no manure (MCo and CTo) plots. The influence of poultry manure application in improving the soil physical conditions had been widely reported (Weil and Kroontje, 1979; Khaleel et al., 1981; Pagliai et al., 1987; Mbagwu, 1992; Akanni, 2005). The improvement in soil physical properties with increasing levels of poultry manure is attributable to increase in soil organic matter from the manure. The organic matter should have stabilized soil structure thereby reducing bulk density, increasing porosity and water content. Sommerfeldt and Chang (1985) found that surface $(0-15 \mathrm{~cm})$ soil bulk density decreased from $0.96 \mathrm{Mg} \mathrm{m}^{-3}$ with no manure to $0.78 \mathrm{Mg} \mathrm{m}^{-3}$ with $90 \mathrm{t} \mathrm{ha}^{-1}$ (wet weight) manure application. Improved soil water content is attributable to mulching effect of organic manure and improved moisture retention and water acceptance as a result of improved soil structure and macroporosity (Aluko and Oyedele, 2005). The improvement observed in water content of the poultry manure treated plots relative to the untreated plots could also be attributed to the colloidal and hydrophobic nature of the manure.
The least values of soil organic C, N, P, K, $\mathrm{Ca}$ and $\mathrm{Mg}$ recorded for CTo could be adduced to inversion of top soil during land preparation which brought less fertile sub soil to the surface in addition to possible leaching (Ali et al., 2006). The decline in the nutrient reserves of the conventionally tilled plots could also be due to high destruction of the soil structure during the land preparation which encourages soil erosion that preferentially removes colloidal fraction with high "enrichment ratio" (Lal, 1976; Agbede, 2008), resulting in a progressive depletion of its nutrient reserves. Although, there was a decrease in soil organic $\mathrm{C}$ concentration with time, the reduction due to MCo was less compared with CTo. Therefore, tillage seems to have enhanced soil organic matter break down leading to a greater loss of soil organic matter in CTo plots (Doran, 1980; Lal, 1997; Agbede and Ojeniyi, 2009). A similar observation was made by Agboola (1981) and Agbede (2007) when they found that organic matter of tropical soils decreased less when no-tillage practices were used than when soils were ploughed.

Increased in soil nutrient contents adduced to poultry manure are consisted with analysis recorded for manure in the present work. The organic matter content of poultry manure decomposes and nutrients were released to soil. Hence, the finding that poultry manure increased soil organic $\mathrm{C}, \mathrm{N}, \mathrm{P}, \mathrm{K}, \mathrm{Ca}$ and $\mathrm{Mg}$. This is consistent with the findings of kingery et al. (1993); Adeniyan and Ojeniyi (2005); Adenawoola and Adejoro (2005); Agbede et al. (2008) and Adekiya and Agbede (2009) that poultry manure improved soil organic matter, $\mathrm{N}, \mathrm{P}, \mathrm{K}, \mathrm{Ca}$ and $\mathrm{Mg}$ concentrations. In both the manually cleared and conventionally tilled plots, increasing levels of poultry manure from 0 to $15 \mathrm{t} / \mathrm{ha}$ reduced soil $\mathrm{pH}$. Ewulo et al. (2008) had earlier found that application of poultry manure in excess of crop requirement may lead to reduction in soil $\mathrm{pH}$. The reduction in the soil $\mathrm{pH}$ could be due to the humic acid developed and carbon dioxide evolved in the process of the decomposition of the applied poultry manure. The significant higher leaf nutrient 
concentration of CTo compared with $\mathrm{MCo}$ was adduced to reduced soil bulk density (Agbede, 2006).

CTo significantly increased vine length and leaf area compared with MCo, this could be adduced to reduced bulk density and improved porosity due to tillage. The better yield of CTo compared with MCo was also due to reduced bulk density and increased porosity. Ravindran and Mohankumar (1985) and Howeler et al. (1993) also reported the superiority of planting sweet potato on ridges, raised beds or mounds (where bulk density is low) than on the flat. This was attributed to enhanced soil aeration, resulting from both a greater soil surface to soil volume ratio and a lower bulk density. These attributes would have enhanced root growth and nutrient uptake, hence better growth and tuber yield in conventionally tilled treatments than untilled treatments. Further evidence of the detrimental effect of high soil bulk density on sweet potato yield was reported by trials in the Philippines (Abenoja and Baterna, 1982). While erosion was least for zero tillage, root yields were reduced below those of tilled treatments owing to a high bulk density and high mechanical impedance. It was found that growth and yield parameters in both the tilled and untilled plots increased with poultry manure to $5 \mathrm{t} / \mathrm{ha}$ and that soil organic $\mathrm{C}, \mathrm{N}, \mathrm{P}, \mathrm{K}, \mathrm{Ca}$ and $\mathrm{Mg}$ increased with amount of poultry manure and bulk density and temperature were reduced while water content was increased. Therefore it is confirmed that poultry manure improved nutrient availability in soil and improved physical conditions leading to significant improvement in nutrient status, growth and tuber yield of sweet potato. The yield of sweet potato was optimum at $5 \mathrm{t} /$ ha poultry manure. The reason that could cause lack of significant effect of sweet potato beyond $5 \mathrm{t} /$ ha poultry manure could be due to soil acidity and nutrient imbalance. It was generally found that soil $\mathrm{pH}$ tended to be reduced with increasing amount of animal manure (Chang et al., 1991; Eghball and Power, 1999). High rate of poultry manure could have led to excessive release of carbon dioxide $\left(\mathrm{CO}_{2)}\right.$ and probably nitrate $\left(\mathrm{NO}_{3}{ }^{-}\right)$into the soil leading to reduced
$\mathrm{pH}$. Excess $\mathrm{N}$ and $\mathrm{P}$ in the soil and acidity could cause nutrient imbalance in sweet potato and therefore resulting in the reduction in the uptake of certain nutrients (Obi and Akinsola, 1995; Eghball, 2002). Hence it was found in this work that leaf $\mathrm{Ca}$ and $\mathrm{Mg}$ of sweet potato were reduced at $15 \mathrm{t} /$ ha poultry manure in both the manually cleared and conventionally tilled plots.

\section{Conclusion}

Differences in soil bulk density caused by tillage induced variation in nutrient concentrations, vine length, leaf area and tuber weight of sweet potato. Higher growth and yield was obtained with conventional tillage with the lowest soil bulk density. Poultry manure is an effective source of $\mathrm{N}, \mathrm{P}, \mathrm{K}, \mathrm{Ca}$, $\mathrm{Mg}$ and organic $\mathrm{C}$ for increasing growth and yield of sweet potato. Because the yields given by 5,10 and $15 \mathrm{t} /$ ha poultry manure were not significantly different under both the manually cleared and conventionally tilled plots, high rates of poultry manure above 5 t/ha had no significant yield advantage. Therefore the use of $5 \mathrm{t} /$ ha poultry manure with conventional tillage is recommended for sweet potato grown on Alfisol of southwest Nigeria.

\section{References}

Abenoja, E. A. and J. P. Baterna. 1982. Tillage practices in continuous hill side farming of root crops. Radix 4:9-11.

Adekiya, A. O. and S. O. Ojeniyi. 2002. Evaluation of tomato growth and soil properties under method of seedling bed preparation in an Alfisol in the rainforest zone of southwest Nigeria. Soil Tillage Res. 64:275-279.

Adekiya, A. O. and S. O. Ojeniyi. 2008. Effect of tillage and poultry manure on soil physical properties and yield of cocoyam in southwest Nigeria. In: Proceedings of the 4th Annual Conference of School of Agriculture and Agricultural Technology, Federal University of Technology, Akure, Nigeria. pp. 159-162.

Adekiya, A. O. and T. M. Agbede. 2009. Growth and yield of tomato (Lycopersicon 
esculentum Mill) as influenced by poultry manure and NPK fertilizer. Emir. J. Food Agric. 21(1):10-20.

Adenawoola, A. R. and S. A. Adejoro. 2005. Residual effects of poultry manure and NPK fertilizer residues on soil nutrient and performance of jute (Corchorus olitorius L). Nigerian J. Soil Sci. 15:133-135.

Adeniyan, O. N. and S. O. Ojeniyi. 2005. Effect of poultry manure, NPK 15-15-15 and combination of their reduced levels on maize growth and soil chemical properties. Niger. J. Soil Sci. 15:34-41.

Agbede, T. M. and S. O. Ojeniyi. 2003. Effect of land preparation methods on soil properties and yield of yam grown on Alfisols. Niger. J. Soil Sci. 13:68-75.

Agbede, T. M. 2006. Effect of tillage on soil properties and yam yield on an Alfisol in southwestern Nigeria. Soil Tillage Res. $86: 1-8$

Agbede, T. M. 2007. Effects of zero tillage on cassava (Manihot esculenta Crantz) in southwestern Nigeria. Niger. J. Soil Sci. 17:81-86.

Agbede, T. M. 2008. Nutrient availability and cocoyam yield under different tillage practices. Soil Tillage Res. 99:49-57.

Agbede, T. M., S. O. Ojeniyi and A. J. Adeyemo. 2008. Effect of poultry manure on soil physical and chemical properties, growth and grain yield of sorghum in southwest Nigeria. Am. Eur. J. Sust. Agric. 2(1):72-77.

Agbede, T. M. and S. O. Ojeniyi. 2009. Tillage and poultry manure effects on soil fertility and sorghum yield in southwestern Nigeria. Soil Tillage Res. 104:74-81.

Agboola, A. A. 1981. The effect of different soil tillage and management practices on the physical and chemical properties of soil and maize yield in a rainforest zone of western Nigeria. Agronomy J. 73:243-251.

Akanni, D. I. 2005. Response of nutrient composition and yield components of tomato (Lycopersicon esculentum Mill) to livestock manure. Ph.D Thesis, Department of Crop, Soil and Pest Management, Federal University of Technology, Akure, Nigeria.

Ali, A., S. A. Ayuba and S. O. Ojeniyi. 2006. Effect of tillage and fertilizer on soil chemical properties, leaf nutrient content and yield of soyabean in the guinea savanna zone of Nigeria. Niger. J. Soil Sci. 16:126-130.

Aluko, O. B. and D. J. Oyedele. 2005. Influence of organic waste incorporation on changes in selected soil physical properties during drying of a Nigerian Alfisol. J. App. Sci. 5:357-362.

Anikwe, M. A. N. and J. N. Ubochi. 2007. Short term changes in soil properties under tillage systems and their effect on sweet potato (Ipomoea batatas L.) growth and yield in an Ultisol in southeastern Nigeria. Austr. J. Soil Res. 45(5):351-358.

Ano, A. O. and J. A. Agwu. 2005. Effect of animal manures on selected soil chemical properties (1). Niger. J. Soil Sci. 15:14-19.

AOAC. 1997. Official Methods of Analysis. $16^{\text {th }}$ Ed., vol. 972: 43. Association of Official Analytical Chemists International, Arlington, VA.

Bankole, E. A. and S. O. Ojeniyi. 2005. Comparative effect of ridge, furrow and zero tillage on cowpea at Abeokuta and Akure, Nigeria. Niger. J. Soil Sci. 15: 5459.

Bremner, J. M. 1996. Nitrogen-total. In: D. L. Sparks (Ed.). pp. 1085-1121. Methods of Soil Analysis. Part 3. Chemical Methods. $2^{\text {nd }}$ edition, SSSA Book Series No. 5, ASA and SSSA, Madison, WI, USA.

Campbell, D. J. and J. K. Henshall. 1991. Bulk density. In: K. A. Smith and C. E. Mullins (Eds.). pp. 329-366. Physical Method of Soil Analysis. Marcel Dekker, New York.

Carter, M. R. 1993. Soil Sampling and Methods of Analysis. Canadian Society of 
Soil Science, Lewis Publishers, London. pp.823

Chang, C., T. G. Sommerfeldt and T. Entz. 1991. Soil chemistry after eleven annual applications of cattle feedlot manure. J. Environ. Qual. 20:475-480.

Doran, J. W. 1980. Soil microbial and biochemical changes associated with reduced tillage. Soil Sci. Soc. Amer. J. 44:765-777.

Eghball, B. and J. F. Power. 1999. Phosphorus and nitrogen based manure and compost application: Corn production and soil phosphorus. Soil Sci. Soc. Amer. J. 63: 895-901.

Eghball, B. 2002. Soil properties as influenced by phosphorus and nitrogen based manure and compost application. Agron. J. 94:128-135.

Ewulo, B. S., S. O. Ojeniyi and D. A. Akanni. 2008. Effect of poultry manure on selected soil physical and chemical properties, growth, yield and nutrients status of tomato. Afr. J. Agric. Res. 3:612-616.

Frank, K., D. Beegle and J. Denning. 1998. Phosphorus. In: J. R. Brown (Ed.), pp. 2126. Recommended Chemical Soil Test Procedures for the North Central Region. North Central Region Research Publication No. 221 (revised) Missouri Agric. Exp. Stn., Columbia, MO.

Hendershot, W. H. and H. Lalande. 1993. Ion exchange and exchangeable cations. In: M. R. Carter (Ed.), vol. 19:167-176. Soil Sampling and Methods of Analysis. Canadian Society of Soil Science, Lewis Publishers, London.

Hillet, D. I., C. H. M. Van Bavel and H. Talpas. 1975. Dynamic stimulation of water storage in fallow soil as affected by mulch of hydrophobic aggregates. Soil Sci. Soc. Amer. Proc. 39:826-833.

Hinkelmann, K. and O. Kempthrone. 1994. Design and Analysis of Experiments, Vol. 1. Introduction to Experimental Design. John Wiley \& Sons. New York, 495 pp.
Howeler, R. H., H. C. Ezumah and D.J. Midmore. 1993. Tillage systems for root and tuber crops in the tropics. Soil Tillage Res. 27:211-240.

Ibitoye, A. A. 2006. Laboratory Manual on Basic Soil Analysis. 2 ${ }^{\text {nd }}$ Ed. 82 pp. Foladave Publishing Company, Akure, Ondo State. Nigeria.

Ikpe, F. N., J. M. Powel, N. O. Isirimah, A. T. Wahua and E. N. Ngodigha. 1999. Effect of primary tillage and soil amendment practices on pearl millet yield and nutrient uptake in the Sahel of West Africa. Exp. Agric. 35:437-448.

Ikpe, F. N. and J.M. Powel. 2003. Nutrient cycling practices and changes in soil properties in the crop livestock farming system of west Niger Republic of West Africa. Nutr. Cycl. Agroecosys. 62:37-45.

Khaleel R., K. R. Reddy and M.R. Overcash. 1981. Changes in soil physical properties due to organic waste applications. A review. J. Environ. Qual. 10:133-141.

Kingery, W. L., C. W. Wood and D. P. Delaney. 1993. Impact of long-term application of broiler litter on environmentally related soil properties. J. Environ. Qual. 23:139-147.

Lal, R. 1976. Soil erosion problems on Alfisols in western Nigeria and their control. IITA Monograph Series No. 1, Ibadan, Nigeria, pp.208

Lal, R. 1997. Long-term tillage and maize monoculture effect on an Alfisol in western Nigeria. Crop yield and soil physical properties. Soil Tillage Res. 47:145-160.

Mbagwu, J. S. C. 1992. Improving the productivity of a degraded Ultisol in Nigeria using organic and inorganic amendments II. Changes in physical properties. Biores. Tech. 42:167-175.

Mbah, C. N. and J. S. C. Mbagwu. 2006. Effect of animal waste on physicochemical properties of a Dystric Leptosol 
and maize yield in southeastern Nigeria. Niger. J. Soil Sci. 16:96-103.

Midmore D. J. 1991. Potato production in the tropics. In: Harris, P. M. (Ed.). The Potato Crop. The Scientific Basis for Improvement. $2^{\text {nd }}$ ed. Chapman and Hall, In press.

Nelson D. W. and L. E. Sommers. 1996. Total carbon, organic carbon and organic matter. In: D. L. Sparks (Ed.), pp. 961-1010. Methods of Soil Analysis. Part 3. $2^{\text {nd }}$ ed., SSSA Book Series No. 5, SSSA, Madison, WI., USA.

Nyakatawa, E. Z., K. C. Reddy and K. R. Sistani. 2001. Tillage, cover cropping and poultry litter effects on soil chemical properties. Soil Tillage Res. 58:69-79.

Obi, O. A. and A. O. Akinsola. 1995. The effect of lime application on the yield of tomato and chemical properties of an Iwo soil in southwestern Nigeria. Niger. J. Soil Sci. 11:77-78.

Obi, M. E. and P. O. Ebo. 1995. The effect of organic and inorganic amendments on soil physical properties and maize production in a severely degraded sandy soil in southern Nigeria. Biores. Tech. 51:117123.

Ojeniyi, S. O. 1990. Effect of bush clearing and tillage methods on soil physical and chemical properties of humid tropical Alfisol. Soil Tillage Res. 15:269-277.

Ojeniyi, S. O., A. O. Adetoro and S. A. Odedina. 1999. Effect of manual tillage methods on soil density, moisture content and cowpea grain yield. J. Agric. Tech. $7: 16-19$.

Ojeniyi, S. O. and F. O. Adekayode. 1999. Soil conditions and cowpea and maize yield produced by tillage methods in the rainforest zone of Nigeria. Soil Tillage Res. 51:161-164.

Okalebo, J. R., K. W. Gathua and P. L. Woomer. 1993. Laboratory Methods of Soil and Plant Analysis. A Working
Manual, TSBF. Soil Science Society of East Africa Publication No. 1, pp.88.

Osundare, B. 2004. Effects of fertilizer types and different companion crops on the performance of sweet potato. Moor J. Agric. Res. 5:88-94.

Pagliai, M. M., Marca la and G. Luca Mante. 1987. Changes in soil porosity in remolded soil treated with poultry manure. Soil Sci. 144:128-140.

Ravindran, C. S. and C. R. Mohankumar. 1985. Effect of method of land preparation and depth of planting on yield of sweet potatoes. In: T. Ramanujam, S. P. Ghosh, J. S. Jos, S. M. Morrthy and R. G. Nair (Eds.). pp. 129-133. Tropical Tuber Crops Production and Utilization. Proc. National Symposium on Production and Utilization of Tropical Tuber Crops, 27-29 Nov., Central Tuber Crops Research Institute Trivandrum, India.

Sheldrick, B. and C. Hand Wang. 1993. Particle-size distribution. In: M. R. Carter (Ed.), pp. 499-511. Soil Sampling and Methods of Analysis. Canadian Society of Soil Science, Lewis Publishers. Ann Arbor, MI.

Sommerfeldt, T. G. and C. Chang. 1985. Changes in soil properties under annual applications of feedlot manure and different tillage practices. Soil Sci. Soc. Amer. J. 49:983-987.

Weil, R. R. and W. Kroontje. 1979. Physical conditions of a Davidson clay loam after five years of heavy poultry applications. J. Environ. Qual. 8:387-392.

Zingore Mafongoya, S. P., P. Myamngafata and K. F. Giller. 2003. Nitrogen mineralization and maize yields following applications of tree pruning to a sandy soil in Zimbabwe. Agrofor. Syst. 57:199-21. 